\title{
PERKEMBANGAN DATABASE PADA BORLAND DELPHI
}

\section{EKA MEI RISTIANTI \\ 16500091}

Fakultas Komputer, 448757160

ekameiristianti.student@umitra.ac.id

\begin{abstract}
Borland delphi adalah bahasa pemrograman yang bekerja dalam lingkup Ms-windows yang merupakan pengembangan bahsa pascal yang bersifat visual. Ide Munculnya delphi sendiri berasal dari bahasa pemrograman yang cukup terkenal yaitu pascal. Karena pemrograman windows masih dirasa cukup sulit, sejak tahun 1993Borland International mengembangkan bahsa pascal yang bersifat visual. Borland delphi dapat memanfaatkan kemampuan MS-Windowssecara optial.

Kemampuannya dapat dipakai untuk merancang program aplikasi yang berpenampilan seperti lainnya bersifat Ms-Windows. Khusus untuk pemrograman database, borlangd delphi menyediakan fasilitas objek yang sangat kuat dan lengkap, sehingga memudahkan programer dalam membuat program untuk aplikasi databse. Selain menyediakan format databse sendiri, yaitu format databse paradox dan dBase, Borland delphi juga dapat menangani berbagai macam format databse antara lain msaccess , ODBC, SyBase, Oracle dan lain lain.

Database sendiri merupakan kumpulan data yang saling berhubungan. Hubungan antar data dapat ditunjukan dengan adanya field/kolom kunci dari tiap file/tabel yang ada. Dalam satu file atau tabel terdapat pada record-record yang sejenis, sama besar sma bentuk, dan merupakan suatu kumpulan entitas yang seragam. Satu record (umumnya digambarkan dengan baris data ) terdiri dari field yang saling berhubungan menunjukan bahwa field tersebut dalam satu pengertian yang lengkap dan disimpan dalam suatu record.
\end{abstract}




\section{A. INTRODUCTION}

Borland delphi adalah bahasa pemrograman yang bekerja dalam lingkup Ms-windows yang merupakan pengembangan bahasa pascal yang bersifat visual. Ide Munculnya delphi sendiri berasal dari bahasa pemrograman yang cukup terkenal yaitu pascal. Karena pemrograman windows masih dirasa cukup sulit, sejak tahun 1993 Borland International mengembangkan bahasa pascal yang bersifat visual. Borland delphi dapat memanfaatkan kemampuan MSWindows secara optimal.

Kemampuannya dapat dipakai untuk merancang program aplikasi yang berpenampilan seperti lainnya bersifat Ms_Windows. Khusus untuk pemrograman database, borlangd delphi menyediakan fasilitas objek yang sangat kuat dan lengkap, sehingga memudahkan programer dalam membuat program untuk aplikasi databse. Selain menyediakan format databse sendiri, yaitu format databse paradox dan dBase, Borland delphi juga dapat menangani berbagai macam format databse antara lain ms- access, ODBC, SyBase, Oracle dan lain lain.

Delphi menyediakan fasilitas yang lengkap untuk mengolah databse. Berbagai format databse diolah oleh delphi, misalnya databse dengan format paradox, dBASE, M-Access, ODBC, Oracle, SQL server dan lain lain.

Sebelum delphi, borland sudah lama mengeluarkan program untuk manajemen databse yang sangat terkenal yaitu program parax. Dengan delphi, kemampuan yang ada pada program paradox menjadi lebih baik dan makin sempurna.

Pada database lokal, format database yang dipakai adalah format paradox, dBASE, atau Access. Dtabase lokal ini juga dapat dipakai untuk aplikasi multi use, tetapi tdak mempunyai kemampuan aplikasi Client-server. Perbedaan dasar sistem multi user dan client-server adalah bahwa pada sistem multi user, server hanya menyediakan data semua proses manipulasi yang dilakukan komputer client. Sedangkan 
pada sistem client_server, selain server menyediakan data, terdapat juga pembagian beban tugas antara client dan server pada proses manipulasi.

Untuk mengolah database dengan data yang cukup besar dan user yang cukup banyak, sebaiknya dipakai format database yang mendukung clientserver, misalnya SyBASE, Oracle, SQL server.

Di dalam pemrograman Borland Delphi Database sangat erat kaitannya. Database sendiri adalah kumpulan dari data-data yang membentuk suatu berkas (file) yang saling berhubungan (relation) dengan tatacara yang tertentu untuk membentuk suatu data baru atau informasi. Atau basis data (database) merupakan kumpulan dari data yang saling berhubungan (relasi) antara satu dengan yang lainnya yang diorganisasikan berdasarkan skema atau struktur tertentu. Pada komputer, basis data disimpan dalam perangkat hardware penyimpan, dan dengan software tertentu dimanipulasikan untuk kepentingan atau kegunaan tertentu. Hubungan atau relasi data biasanya ditunjukan dengan kunci (key) dari tiap file yang ada. Data merupakan fakta atau nilai (value) yang tercatat untuk mempresentasikan deskripsi dari suatu objek. Data yang merupakan fakta yang tercatat dan selanjutnya dilakukan pengolahan (proses) menjadi bentuk yang berguna atau bermanfaat bagi penggunanya akan membentuk apa yang disebut informasi

Ini merupakan contoh Database pada pemrograman borland delphi

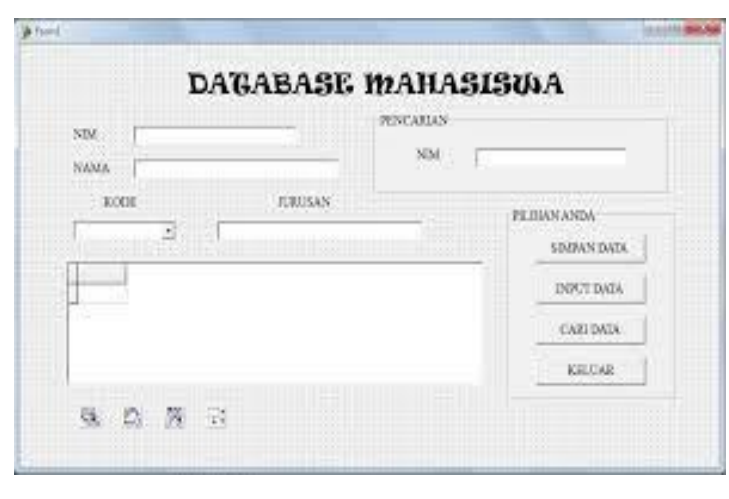

Basis Data ( database ) mempunyai beberapa kriteria penting yaitu :

1. Memiliki sifat data oriented bukan progrm oriented

2. Dapat digunakan oleh beberapa program aplikasi tanpa perlu mengubah databsenya. 
3. Dapat dikembangkan dengan mudah, baik volume maupun strukturnya.

4. Dapat memenuhi kebutuhan sistem sistem baru secara lebih mudah.

5. Dapat digunakan dengan cara cara yang berbeda.

Adapn ciri ciri dari databse yaitu :

1. Lebih efisien, meliputi kecepatan, ukuran dan ketepatan.

2. Data dalam jumlah besar

3. Dapat dipakai secara bersamasama'

4. Mengurangi bahkan dapat menghilangkan terjadinya duplikasi dan ketidaksonsistenan data.

Delphi menyediakan cukup banyak object dengan berbagai variasi untuk mengolah suatu file database yang sudah anda buat. Awalnya bahasa pemrogrman delphi hanya dapat digunakan di Microsoft Windows, namun saat ini telah dikembangkan sehingga dapat digunakan juga di
Linux dan Microsoft .NET. dengan menggunakan free pascal yang merupakan proyek open source, bahasa pemrograman ini dapat membuat program di sistem operasi Mac OS X dan Windows CE.

Umumnya delphi hanya digunakan untuk pengembangan aplikasi dekstop, enterprise berbasis database dan program program kecil. Namun karena pengembangan delphi yang semakin pesat dan bersifat general purpose bahasa pemrograman ini mampu digunakan untuk berbagai jenis pengembangan software. Dan delphi juga disebut sebagai pelopor perkembangan RadTool ( Rapid Application Development ) tahun 1995. Sehingga banyak orang yang mulai mengenal dan menyukai bahasa pemrograman yang bersifat VCL ( Visual Component Libarry ) ini.

Perkembangan Borland Delphi :

1. Delphi versi 1 ( berjalan pada windows 3.1 atau windows 16 bit ) 
2. Delphi versi 2 ( berjalan pada windows 95 atau windows 32 bit )

3. Delphi versi 3 ( berjalan pada windows 95 keaatas dengan tambahan fitur internet atau web)

4. Perkembangan selanjutnya diikuti dengan delphi 4, 5 dan 6

5. Versi terkini dari delphi adalah versi 7 dengan tmbahan vitur .net dengan tambahan file XML

\section{B. CONCLUSION}

Dari penjelasan di atas dapat di simpulkan bahwa Borland Delphi sangat erat kaitannya dengan database.

Database sendiri merupakan kumpulan data yang saling berhubungan. Hubungan antar data dapat ditunjukan dengan adanya field/kolom kunci dari tiap file/tabel yang ada. Dalam satu file atau tabel terdapat pada recordrecord yang sejenis, sama besar sma bentuk, dan merupakan suatu kumpulan entitas yang seragam. Satu record (umumnya digambarkan dengan baris data ) terdiri dari field yang saling berhubungan menunjukan bahwa field tersebut dalam satu pengertian yang lengkap dan disimpan dalam suatu record.

Umumnya delphi hanya digunakan untuk pengembangan aplikasi dekstop, enterprise berbasis database dan program program kecil. Namun karena pengembangan delphi yang semakin pesat dan bersifat general purpose bahasa pemrograman ini mampu digunakan untuk berbagai jenis pengembangan software.

Ide munculnya delphi sebenarnya berasal dari bahasa pemrograman yang cukup terkenal yaitu pascal, karenA pemrograman windows dengan turbo pascal masih dirasa cukup sulit, sejak tatuhn 1993 Borland International mengembangkan database bahasa pascal yang bersifat visual. Hasil dari prngembangan ini ialah dirilisnya delphi satu pada tahun 1995 .

Perkembangan delphi tisak hanya berhenti sampe situ, tahun berikutnya 1996 borland erilis delphi 2 untuk win 96/NT 
Dalam tahun tahun berikutnya borland delphi merilis beberapa versi pengembangan delphi sehingga kita mengenal borland delphi 6 .

\section{ACKNOWLEDGEMENT} University Of Indonesia University Of Mitra Indonesia Telkom University University Of Mellbourne Saitama University

\section{REFERENCE (Based ISO 690 )}

A. S. Putra And O. M. Febriani,
"Knowledge
Online Application In Pdam
Lampung Province," In
Prosiding r International
Conference On Information
Technology And Business
(Icitb), 2018, Pp. 181-187.

[2] A. S. Putra, O. M. Febriani, And B. Bachry, "Implementasi Genetic Fuzzy System Untuk Mengidentifikasi Hasil Curian Kendaraan Bermotor Di Polda Lampung," J. Sist. Inf. Dan Manaj. Basis Data, Vol. 1, No. 1, Pp. 21-30, 2018.

[3] O. M. Febriani And A. S. Putra, "Sistem Informasi Monitoring Inventori Barang Pada Balai Riset Standardisasi Industri Bandar Lampung," J. Inform., Vol. 13, No. 1, Pp. 90-98, 2014.

[4] Putra, Arie Setya. "2018 Artikel Struktur Data, Audit Dan Jaringan Komputer." (2018).
[5] Putra, A. S. (2018, July 17). Paperplain Fundamental Create Application With Borland Delphi 7.0 University Of Mitra Indonesia. Retrieved From Osf.Io/Pbrn9.

\section{E. REFERENCE (Based APA)}

Putra, A. S., Aryanti, D. R., \& Hartati, I. (2018, November). Metode SAW (Simple Additive Weighting) sebagai Sistem Pendukung Keputusan Guru Berprestasi (Studi Kasus: SMK Global Surya). In Prosiding Seminar Nasional Darmajaya (Vol. 1, No. 1, pp. 85-97).

Sari, D. P., Febriani, O. M., \& Putra, A. S. (2018, November). Perancangan Sistem Informasi SDM Berprestasi pada SD Global Surya. In Prosiding Seminar Nasional Darmajaya (Vol. 1, No. 1, pp. 289-294).

Putra, A. S. (2018). Paperplain: Execution Fundamental Create Application With Borland Delphi 7.0 University Of Mitra Indonesia.

Putra, A. S., Sukri, H., \& Zuhri, K. Sistem Monitoring Realtime Jaringan Irigasi Desa (JIDES) Dengan Konsep Jaringan Sensor Nirkabel. IJEIS (Indonesian Journal of Electronics and Instrumentation Systems), 8(2), 221232.

Darmawan, A., Yuliawati, D., Marcella, O., \& Firmandala, R. (2016). Sistem Absensi dan Pelaporan Berbasis Fingerprint dan SMS Gateway. EXPLORE, 7(1). 
Febriani, O. M., Wahyuni, T., \& Yusuf, S. (2017). DESIGN OF WEBSITE-BASED INFORMATION SYSTEM FOR EDOCUMENT

ADMINISTRASI IN THE
COMMUNITY SERVICE UNIT (A Case Study at Rajabasa District). INTERNATIONAL JOURNAL OF COMPUTERS \& TECHNOLOGY, 16(7), 7010-7020.

Febriani, O. M., \& Wahyuni, T. (2017, October). PERANCANGAN SISTEM E-DOCUMENT ADMINISTRASI LOGBOOK PENELITIAN PADA UNIT LAYANAN DI BANDAR LAMPUNG. In Prosiding Seminar Nasional Darmajaya (Vol. 1, No. 1, pp. 187-194).

Febriani, O. M., \& Permadi, A. B. (2017). Implementasi Sistem Aplikasi Data Bimbingan dan Pelanggaran Siswa pada Sekolah Menengah Atas di Lampung Tengah dengan Metode Analisis dan Desain Sistem Terdistribusi (SSAD). EXPERT, 7(1).

Febriani, O. M., \& Ambarwati, L. (2015). PERANCANGAN APLIKASI PENGOLAHAN DATA PENJUALAN UKM KELANTING KHAS TELO DESA SIDOHARJO KECAMATAN JATI AGUNG KABUPATEN LAMPUNG SELATAN. Jurnal Teknologi Informasi dan Bisnis Pengabdian Masyarakat Darmajaya, 1(1), 77-95.

Febriani, O. M. (2015). Rancang Bangun Aplikasi Ecommercemenggunakan Freewebstore pada UKM Kelanting di Desa Sidoharjo Lampung Selatan. Prosiding Sembistek 2014, 1(02), 446-458. 